\title{
PHYSICOCHEMICAL CHARACTERISTICS AND SENSORY EVALUATION OF CORN AND SORGHUM DRY MASA FLOURS IN RELATION TO PACKAGING MATERIALS AND STORAGE CONDITIONS \\ Hussein, A. M. S. ${ }^{*}$ and Nefisa A. Hegazy \\ Food Technology Dep., National Research Centre, Dokki, Cairo, Egypt
}

\begin{abstract}
Dry masa flours were prepared from white, yellow corn or sorghum according to standard methods. The flours were then packed in bags made from jute; kraft paper, polyethylene or poly ethylene textile. The packages were stored at ambient temperature $\left(24-32^{\circ} \mathrm{C}\right)$ for extended periods of time up to 6 months. All the fresh and stored masa flours (72 samples) were subjected to physicochemical characterization including: water vapor transmission; the amylograph profiles, liped quality and the sensory scoring. The results demonstrated that the conversion of the cereal grains into the respective masa was associated with enrichment in the calcium content due to treatment with lime. Polyethylene bags were superior compared to the three other packaging materials in maintaining the water vapor transmission of the masa flour at a low rate due to high resistance against tearing. The physicochemical properties and sensory scoring of the masa flours remained acceptable for samples stored for a period of two months at ambient temperature. The kraft bags and polyethylene bags proved to be unsafe due to rapid lipid rancidity and / or the growth of insects. Prolonged storage is not recommended since it was associated with rapid drop in the physicochemical properties and the sensory scoring of the masa flours.

Keywords: Masa flour, water vapor transmission, amylograph peak viscosity, lipid oxidation, sensory evaluation, packaging materials, storage at ambient temperature
\end{abstract}

To whom correspondence should be made : a_said22220@yahoo.com

\section{INTRODUCTION}

Corn is considered as one of the principle crops in Egypt and its production is increasing steadily; however, the majority of the crop is directed for animal and poultry feeding, in spite of the shortage in the cereal-based foodstuffs. Sorghum is the fifth most important cereal in total world production and its composition and properties are quite similar to those of maize (Anon, 2000). Sorghum is a substitute for corn in some Latin American Countries because it produces higher grain yields, is cheaper and has nutritional value quite similar to that of corn. Therefore, it would be beneficial to introduce new manufactured corn and sorghum products to the Egyptian food market such as Tortillas. Tortillas are traditionally prepared according to the ancient Aztec process by cooking the corn kernels in alkaline lime, steeping, washing steps to get rid of excess alkali, drying and finally stoneground.

Dry masa flour is manufactured by cooking corn with lime and then grinding the resulting nixtamal into masa. The wet masa is then dried, ground, sieved and blended to yield a shelf-stable product of desired color, particle size, pH, water uptake and flavor (Gomez et al., 1987). Masa is shaped into tortillas which are then baked on a hot-griddle or gas-fired oven 
(Rooney and Serna-Saldivar, 1987). The use of dry masa flour is gaining popularity due to its prolonged shelf-life and convenience in handling. The demand for instant dry corn masa is increasing in Mexico and the United States. Since considerable less work is required for consumer preparation when using precooked flour than when using raw corn (Gomez et al., 1987). It is estimated that approximately $20 \%$ of the Mexico, population use at home commercial dry masa flour (Sanchez-Marroquin et al., 1987).

Significant changes in fat acidity, protein digestibility, and protein efficiency ratio, sensory properties had been reported throughout storage of masa flour in desiccators containing saturated salt solution to produce environments with relative humidities ranging from $55-83 \%$ (Pardes and Mora, 1983).

Autoxidation of oil had been reported to cause off-flavors and offodors of dry corn masa flours, which reduced consumer acceptability of the corn tortillas (Vidal -Quintanar et al., 1993). Furthermore, a shelf-life of 23 weeks was reported for dry corn masa flour stored at $25 \circ \mathrm{C}$; whereas, at high temperatures of $45 \cong \mathrm{C}$ the respective shelf life was shortened to 9 weeks. The shelf-life of instant dry corn masa had been reported to be much longer than the respective one obtained with the traditional wet corn masa.

Off-flavors and off-odors arose from secondary oxidation products (aldehydes, ketones, short chain, fatty acids, etc.). Gas chromatographic head space analysis of these volatile compounds is often used to analyze for these products, but sensory analysis by using human subjects is a more direct measure of off-flavor and off odors (Przybylski and Eskin 1995).

The objectives of the present work was to study the physicochemical characteristics, lipid auto-oxidation and sensory properties of dry masa flour packed in four different types of packaging materials (Jute, kraft paper, polyethylene and polyethylene textile) and stored at ambient temperature $(24-32 \circ \mathrm{C})$ with relative humidity $(\mathrm{RH})$ of $29 \%$ for extended periods of time up to six months.

\section{MATERIALS AND METHODS}

I-Materials:

The grains of white corn (pioneer $30 \mathrm{~K} 8$ ), yellow corn 153 and sorghum were purchased from the Corn Breeding Section, Field Crops Department, Agric. Res. Center, Giza, Egypt.

The packaging bags had a dimension of $20 \times 30 \mathrm{~cm}$ and were made from (a) Jute bags (b) Kaft paper bags (c)Polyethylene bags

(d) Polyethylene textile bags.

ח-Methods:

1-Experimental:

Laboratory process for preparing dry corn masa according to VidalQuintanar et al.,(2001) with some modification as follows: the whole corn grain $(1 \mathrm{~kg})$ were soaked in $1 \%$ calcium hydroxide solution $(1: 3 \mathrm{w} / \mathrm{w}$ ratio) and then cooked for $95 \mathrm{~min}$ on an electronic stove adjusted to $95^{\circ} \mathrm{C}$ by the traditional cooking method for (Fig.1). The nixtamal was steeped over night 
$(15 \mathrm{~h})$ at $24 \pm 1^{\circ} \mathrm{C}$; washing was carried out with $5 \mathrm{~L}$ tap water followed by decantation using a sieve (three times), and then milled. The masa was spread on aluminum foil in a $2.5 \mathrm{~cm}$ layer and dried in convection over at $85^{\circ}$ $\mathrm{C}$ for $6 \pm 0.25 \mathrm{~h}$. The dry masa was electrically ground (Brabender mill (Junior) to pass a 60 mesh screen ( 0.0028 in sieve opening), and a minimum of $0.102 \pm .0 .06 \mathrm{~cm}$ of free space between the shaft and the stationary body of the mill.

The yellow corn and sorghum were treated in a similar manner as the white corn to produce the respective dry masa flour.

Packaging: The masa were distributed into four equal parts; whereas each portion $200 \mathrm{~g}$ was packed in one of the following packaging materials:
A) Jute bags.
B) Kaft paper bags.
C) Polyethylene bags.
D) Polyethylene textile bags

The bags were sealed.

Storage conditions: The bags were stacked on the wooden board $10 \mathrm{~cm}$ above the floor in well ventilated room. The temperature of the room was recorded once a week and it fluctuated between $24-32^{\circ} \mathrm{C}$; whereas the relative humidity was about $29 \%$. Sampling was taken at 0, 2, 4 and 6 months for subsequent chemical analysis and sensory evaluation. 


\section{2-Analytical methods:}

a) Gross chemical composition: Moisture, ether extract, crude protein $(\% \mathrm{~N} \times 6.25)$, crude fiber and ash contents were determined according to AOAC. (1990). Total carbohydrates were calculated by difference

b) Minerals content: Calcium and phosphorus were determined after dry ashing using atomic absorption spectrophotometer according to the method described by Chapman and Pratt (1978).

c)-lipid auto-oxidation:

The acid value $(\mathrm{AV})$, peroxide value (PV) and Thiobarbutric acid number (TBA) were the parameters used for the assessment of lipid autooxidation.

The three parameters were analyzed in the oil extracted from dry masa flours following the method of Habib and Brown(1956). The extracted oil was kept in tightly closed dark bottle in a deep freezer at $\left(20^{\circ} \mathrm{C}\right)$ for subsequent analysis.

Acid value $(A V)$ and peroxide value (PV) have been determined according to the methods of AOAC. (1990). Thiobarbutric acid number (TBA) was determined according to the method described by Pearson (1976).

d) Color: Color of masa flour was measured by using a SpectroColorimeter (Tristimulus Color Machine) with CIF lab color scale (Hunter, Lab Scan XE, Germany).

e) Initial and peak pasting viscosities: A portion of the masa flour (60 $\mathrm{gm}$ ) was suspended in $450 \mathrm{~mL}$ water and the suspension was placed in an amylograph bowel with constant stirring. The temperature was raised at the rate of $1.5^{\circ} \mathrm{C} / \mathrm{min}$ until it reached $95^{\circ} \mathrm{C}$. The temperature was held at this temperature for $20 \mathrm{~min}$. And then it was cooled down to $50^{\circ} \mathrm{C}$ (Tonella et al., 1983). The viscosity was recorded (Brabender amylograph ; Duisburg Nr. 940053, type 680022).

\section{3-Organoleptic evaluation:}

Ten experienced panelists from the staff of Food Technology Department, National Research Center served for the organoleptic. Evaluation of the dry masa flours by using four parameters including color, odor, appearance and overall acceptability. Each parameter was divided into a nines point scale; whereas a score of nine corresponded to "like extremely" and a score of one corresponded to "dislike extremely" (Twillman and While, 1988)

\section{4-Statistical analysis:}

All values were expressed as mean and standard deviation from the mean. The results were statistically analyzed by the analysis of variance and least significant difference (L.S.D at 0.05 level according to Snedecor and Cochran, 1980).

\section{RESULTS AND DISCUSSION}

\section{Chemical evaluation of the raw materials and their dry masa flours A-Gross chemical composition:}

Table (1) presents the chemical composition of the whole grains of white corn, yellow corn and sorghum and the respective three dry masa flours. The results show that the average contents of ether extract, fiber and 
moisture were slightly higher in the whole grains compared with the respective mean values found in the dry masa flours. On the other hand, the dry masa flours were superioe in their protein, ash and total carbohydrates when compared with the respective mean values presented initially. The differences noticed in the chemical composition could be ascribed to the genetic . The slight difference in total protein content between raw materials and dry masa is similar to that reported by Khorshid et al., (1996) Salem et al (1999a),Zahran(2000) and El-Shazly(2001).These differences could be attributed to the losses occurred in the soluble carbohydrates during washing of the cooked grains. Raw grains contained more fat and fiber than corresponding dry masa flour. These results are in agreement with those given by Serna- Saldivar et al (1991), Zahran (2000) and El- Shazly(2001).

Table (1): Summative analysis and Calcium - phosphorus contents of white corn, yellow corn and sorghum and their respective masa flour

\begin{tabular}{|c|c|c|c|c|c|c|c|c|c|}
\hline \multirow[b]{2}{*}{ Components } & \multicolumn{3}{|c|}{ White Corn } & \multicolumn{3}{|c|}{ Yellow Corn } & \multicolumn{3}{|c|}{ Sorghum } \\
\hline & Raw & Masa & $\begin{array}{c}\text { Change } \\
\%\end{array}$ & Raw & Masa & $\begin{array}{c}\text { Change } \\
\%\end{array}$ & Raw & Masa & $\begin{array}{c}\text { Change } \\
\%\end{array}$ \\
\hline Moisture & 11.93 & 9.10 & -23.70 & 12.77 & 8.2 & -35.78 & 10.69 & 9.28 & -13.19 \\
\hline Crude protein & 10.40 & 10.62 & +2.11 & 10.92 & 11.29 & +3.39 & 10.55 & 10.88 & +3.13 \\
\hline Ether extract & 5.04 & 4.00 & -20.63 & 4.45 & 4.12 & -7.42 & 5.26 & 4.50 & -14.45 \\
\hline Crude fiber & 3.22 & 1.96 & -39.13 & 3.09 & 2.50 & -19.09 & 4.12 & 3.02 & -26.70 \\
\hline Ash & 2.35 & 2.50 & +6.38 & 2.63 & 2.80 & +6.46 & 2.16 & 2.30 & +6.48 \\
\hline $\begin{array}{l}\text { Total } \\
\text { carbohydrates }\end{array}$ & 78.77 & 80.92 & +2.73 & 78.54 & 79.29 & +0.95 & 77.60 & 79.3 & -2.19 \\
\hline \multicolumn{10}{|c|}{ Minerals (mg/100gm) } \\
\hline Calcium (Ca) & 28.0 & 141.0 & +403.6 & 35.0 & 140.0 & +300.0 & 43.0 & 178.0 & +313.95 \\
\hline Phosphorus (P) & 220.0 & 223.0 & +1.36 & 210.0 & 238.0 & +13.30 & 240.0 & 240.0 & 0.0 \\
\hline Ca: $P$ ratio & 0.13 & 0.63 & +384.6 & 0.17 & 0.59 & +247.06 & 0.18 & 0.74 & +311.11 \\
\hline
\end{tabular}

\section{B-Minerals content:}

The alkali treatment with diluted calcium hydroxide (1\%) increased calcium content of the dry masa flour almost by 10 fold compared in the respective value in the original cereal. Such increase has been attributed to the lime (Hussein, 2002). Commercial cereal grains are known with their low content in $\mathrm{Ca}$ and availability of minerals in Questionable due to the presented of phytic acid, oxalates and fiber (Kies, 1985). Processing raw grain into tortillas significantly increased the amounts of $\mathrm{Ca}$, improved the $\mathrm{Ca}-\mathrm{P}$ ratio, with in agreement with either reports (Serna-Saldivar et al., 1991).

\section{Pasting properties of corn and sorghum grains}

The gelatinization of starch is associated with obliteration in the starch granules net work and individual linear macromolecules (amylase) diffuse into the aqueous medium increasing its viscosity (Aguilera and Stanely., 1999).

Table (2) presents the important viscosity peaks measurement attained from gelatinization of corn and sorghum starches in water. The obtained data revealed that lime treatment decreased temperature of initial viscosity from 90 to $69{ }^{\circ} \mathrm{C}$ in the case of white and from 80.5 to $70.5{ }^{\circ} \mathrm{C}$ in the case of sorghum. This means that $\mathrm{Ca}(\mathrm{OH})_{2}$ may lead to a more penetrating 
J. Agric. Sci. Mansoura Univ., 32 (9), September, 2007 2 
power of $\mathrm{H}_{2} \mathrm{O}$ into the starch granule, probably due to the decrease of hydrogen bonds in the starch granules. The presence of $\mathrm{Ca}(\mathrm{OH})_{2}$ increased also the corn flour viscosity i.e. from 960 to $1400 \mathrm{BU}$ in the case of the white corn and in the case of sorghum viscosity increased from 520 to $2600 \mathrm{BU}$. The temperature of the max. Viscosity (peak) decreased from 98 to $84{ }^{\circ} \mathrm{C}$ for corn and from 97.5 to $85^{\circ} \mathrm{C}$ in the case of sorghum.

The white corn was considerably lower in terms of the three parameters of measuring viscosity expressed in BU units; i.e, maximum, breakdown and setbacks compared to the respective values obtained with the yellow corn. This finding suggests that the swelling and gelatinization of starch in yellow corn were restricted due to granules tightly locked within endosperm cells (Gomes et al., 1989). Moreover, corn starch seemed to be very resistant to breakdown, keeping a constant viscosity during cooking. (95ㅇ $\mathrm{C}$ hold period). The increase in viscosity upon cooling either the white corn or the yellow corn was attributed to the starch retrogradation i.e the recrystallization or reassociation of gelatinized starch (Bryant \& Hamaker., 1997 and Kamel, 2001).

The major factor in starch gelatinization in granule is swelling which depends on the strength and character of micellar net work within the granule, which in turn is dependent on the degree and kind of association (Bhattachary and Hanna, 1987) which greatly differs between starch types rather than in individual granules of each starch species. Therefore, it could be noticed that the gelatinization level varied according to the type of starch. With regard to viscosity values of two starch types cooked in $1 \%$ lime solution, no relationship could be established between viscosity of starch gelatinized in water and those gelatinized in the presence of lime. It seems that the presence of lime affected both viscosity peak profile and viscosity value.

\section{Effect of packaging and storage conditions on the quality of dry masa flours:}

Table (3) shows the proximate analysis of the different dry masa flour at zero time and after 6 months at room temperature (24-32 $\left.{ }^{\circ} \mathrm{C}\right)$ in the different packaging materials. All dry masa flour stored in polyethylene bags had the lowest moisture loss throughout the storage. The low film, permeability decreased or impeded the diffusion of moisture through the polyethylene material. Moisture content of dry masa flour also decreased as the storage period progressed in the other packaging materials. These findings were in accordance with that of Hegazy et al. (1996) who reported that the moisture content of wheat flour decreased as the storage period progressed. Flour stored in kraft paper bags had the highest fat losses during the storage period. These results are in agreement with earlier reports (Carrello-Perez et al., 1989). Dry masa flour stored for 6 months in jute, kraft paper, polyethylene or polyethylene textile bags contained a similar or even lower protein, ash, and fiber content than that in the original dry masa flour. According to Carrillo-Perez et al., (1989) polyethylene bags are more resistant to tearing with lower rate of water vapor transmission than paper bags; storage in the latter bags led to rapid deterioration. 
Table (3): Effect of packaging materials during 6 month storage on the composition of dry masa flour

\begin{tabular}{|c|c|c|c|c|c|}
\hline \multirow[b]{2}{*}{ Nutrient } & \multirow{2}{*}{$\begin{array}{c}\text { No } \\
\text { storage }\end{array}$} & \multicolumn{4}{|c|}{ After storage for 6 months at ambient temperature } \\
\hline & & Jute & $\begin{array}{l}\text { Kraft } \\
\text { paper } \\
\text { bags }\end{array}$ & $\begin{array}{c}\text { Polyethylene } \\
\text { bags }\end{array}$ & $\begin{array}{c}\text { Polyethylene } \\
\text { textile }\end{array}$ \\
\hline \multicolumn{6}{|c|}{ White corn } \\
\hline Moisture & 9.1 & 6.5 & 8.5 & 8.1 & 7.2 \\
\hline Crude protein & 10.62 & 10.62 & 10.77 & 10.02 & 10.82 \\
\hline $\begin{array}{l}\text { Crude ether- } \\
\text { extract }\end{array}$ & 4.00 & 3.72 & 3.92 & 3.17 & 4.00 \\
\hline Crude Fiber & 1.96 & 1.97 & 1.79 & 1.82 & 1.68 \\
\hline Ash & 2.50 & 2.50 & 2.60 & 2.29 & 2.63 \\
\hline Carbohydrates & 80.92 & 81.12 & 80.92 & 82.7 & 80.87 \\
\hline \multicolumn{6}{|c|}{ Yellow corn } \\
\hline Moisture & 8.2 & 6.8 & 7.8 & 7.2 & 7.4 \\
\hline Crude protein & 11.29 & 11.78 & 11.20 & 11.50 & 11.1 \\
\hline $\begin{array}{l}\text { Crude ether- } \\
\text { extract }\end{array}$ & 4.12 & 3.96 & 4.02 & 3.29 & 4.4 \\
\hline Crude Fiber & 2.50 & 2.50 & 2.30 & 2.47 & 2.27 \\
\hline Ash & 2.80 & 2.71 & 2.80 & 2.76 & 2.66 \\
\hline Carbohydrates & 79.29 & 79.05 & 79.68 & 79.98 & 79.86 \\
\hline \multicolumn{6}{|c|}{ Sorghum } \\
\hline Moisture & 9.28 & 7.3 & 8.9 & 8.6 & 7.9 \\
\hline Crude protein & 10.88 & 10.88 & 10.62 & 10.60 & 10.30 \\
\hline $\begin{array}{l}\text { Crude ether- } \\
\text { extract }\end{array}$ & 4.50 & 4.30 & 4.24 & 3.47 & 4.60 \\
\hline Crude Fiber & 3.02 & 2.88 & 2.95 & 3.00 & 2.90 \\
\hline Ash & 2.30 & 2.40 & 2.22 & 2.20 & 2.36 \\
\hline Carbohydrates & 79.30 & 79.54 & 79.97 & 80.73 & 79.84 \\
\hline
\end{tabular}

Mean hunter color values and the effect packaging materials and storage:

Color is a major criterion that affects the quality of the final product. The stages of dry masa flour processing showed in relation to the grains. Mean hunter color values were affected mainly by the original grain used for the preparation of the masa and by the storage time, whereas, the variation in the packaging materials had little effect on hunter color values. Dry masa flour prepared from white corn was characterized with maximum values of $(L)$ and minimum values of redness (a) and yellowness (b) (Table 4). The dry masa prepared from yellow corn were darker, more yellowish and more greenish than the respective ones obtained with white corn .The color of sorghum products was darker with a slight greenish yellow color presumably produced by unknown reactions of polyphenols with the alkali. Furthermore, increasing the alkali concentration increased the color darkening (AlmeidaDominguez et al., 1991; Hegazy et al., 1996); Salem et al., 1999a). 
Table (4): Mean Hunter color values of dry masa flours at zero time and after 6 months storage in different packaging materials

\begin{tabular}{|c|c|c|c|c|c|c|c|c|}
\hline \multirow{3}{*}{$\begin{array}{l}\text { Packaging } \\
\text { materials }\end{array}$} & \multicolumn{8}{|c|}{ Color } \\
\hline & \multicolumn{4}{|c|}{ Zero time } & \multicolumn{4}{|c|}{ After 6 month } \\
\hline & $\mathbf{L}$ & a & b & $\begin{array}{c}E \\
\text { value }\end{array}$ & $\mathbf{L}$ & a & b & $\begin{array}{c}E \\
\text { value }\end{array}$ \\
\hline \multicolumn{9}{|c|}{ White corn Dry masa flour } \\
\hline Jute bags & 83.01 & 1.08 & 17.77 & 84.89 & 80.07 & 0.69 & 23.97 & 83.40 \\
\hline $\begin{array}{l}\text { Kraft paper } \\
\text { bags }\end{array}$ & 83.01 & 1.08 & 17.77 & 84.89 & 80.69 & 0.66 & 22.96 & 83.89 \\
\hline $\begin{array}{l}\text { Polyethylene } \\
\text { bags }\end{array}$ & 83.01 & 1.08 & 17.77 & 84.89 & 80.41 & 0.55 & 23.10 & 83.65 \\
\hline $\begin{array}{l}\text { Polyethylene } \\
\text { textile bags }\end{array}$ & 83.01 & 1.08 & 17.77 & 84.89 & 80.41 & 0.69 & 22.78 & 83.57 \\
\hline LSD & 1.5 & 0.21 & 0.9 & 0.9 & 0.8 & 0.2 & 0.8 & 0.9 \\
\hline \multicolumn{9}{|c|}{ Yellow corn Dry masa flour } \\
\hline Jute bags & 82.18 & -0.31 & 23.00 & 85.33 & 72.79 & 7.94 & 41.26 & 84.03 \\
\hline $\begin{array}{l}\text { Kraft paper } \\
\text { bags }\end{array}$ & 82.18 & -0.31 & 23.00 & 85.33 & 73.48 & 7.78 & 40.78 & 84.38 \\
\hline $\begin{array}{l}\text { Polyethylene } \\
\text { bags }\end{array}$ & 82.18 & -0.31 & 23.00 & 85.33 & 72.80 & 7.90 & 41.01 & 83.91 \\
\hline $\begin{array}{l}\text { Polyethylene } \\
\text { textile bags }\end{array}$ & 82.18 & -0.31 & 23.00 & 85.33 & 72.64 & 7.89 & 40.90 & 83.72 \\
\hline LSD & 0.14 & 0.3 & 0.2 & 0.9 & 0.80 & 0.2 & 0.13 & 1.5 \\
\hline \multicolumn{9}{|c|}{ Sorghum Dry masa flour } \\
\hline Jute bags & 54.77 & 4.09 & 23.22 & 59.63 & 68.38 & 3.23 & 25.78 & 73.14 \\
\hline $\begin{array}{l}\text { Kraft paper } \\
\text { bags }\end{array}$ & 54.77 & 4.09 & 23.22 & 59.63 & 68.33 & 2.66 & 23.89 & 72.42 \\
\hline $\begin{array}{l}\text { Polyethylene } \\
\text { bags }\end{array}$ & 54.77 & 4.09 & 23.22 & 59.63 & 66.95 & 3.33 & 25.90 & 71.85 \\
\hline $\begin{array}{l}\text { Polyethylene } \\
\text { textile bags }\end{array}$ & 54.77 & 4.09 & 23.22 & 59.63 & 68.1 & 3.14 & 25.46 & 72.76 \\
\hline LSD & 0.80 & 0.21 & 0.20 & 0.14 & 0.30 & 0.14 & 0.90 & 0.90 \\
\hline
\end{tabular}

Dark color is not considered a real disadvantage since even the commercial corn flours varies in color intensity according to the corn grains from which it is produced (Barron and Espinoza., 1993). The storage for 6 months was associated with a slight decrease in the overall color index. Dry masa flour samples in all bags had lower (L) lightness and (a) redness and (b) yellowness values than the control.

\section{Chemical quality attributes:}

Fig. (2-4).illustrates the changes in the acid value (AV) of dry masa flour prepared from white corn, yellow corn and sorghum packed upon storage.Storage for 6 months was associated with double increase in the AV $(3.16-3.86 \mathrm{mg} \mathrm{KOH} / \mathrm{gm}$ oil) compared to the respective initial mean value of $1.76 \mathrm{mg} \mathrm{KOH} / \mathrm{mg}$ oil . The AV of masa 2 increased from $2.08 \mathrm{mg} \mathrm{KOH} /$ gm oil to 4.16, 4.36, 4.52, and $3.64 \mathrm{mg} \mathrm{KOH} \mathrm{/} \mathrm{gm} \mathrm{oil} \mathrm{when} \mathrm{stored} \mathrm{in}$ polyethylene, kraft paper, polyethylene textile, and Jute bags respectively after end of the storage period. The AV of masa 3 increased from $1.96 \mathrm{mg}$ $\mathrm{KOH}$ / gm oil when stored in polyethylene, krafet paper, polyethylene textile, and Jute bags respectively. The results demonstrated that the dry masa packed in Jute bags had lower mean AV after 6 months of storage compared with the the respective AV of dry masa flour packed in other 
packaging materials. These findings are in good agreements with earlier reports (Vidal-Quintanar et al; 2001 ; Hussein, 2002 ; Vidal-Quintanar 2003).

The peroxide value (PV) increased also steadily with the progress of storage; and the packaging material had an effect on the rate of increase in PV. Highest rate of increase in PV (66\% menu. Peroxide / Kg oil) compared to the respective initial mean value was obtained in dry masa packed in polyethylene bags

These results indicated that Jute bags were superior to other packaging material in reducing the oxidation rate of dry masa lipids during storage.

The mean TBA number increased also two to five folds in all the studied samples at the end of the storage period compared with the low initial mean value of. $0.047 \mathrm{mg} \mathrm{Mal} \mathrm{(Figures} 8-10)$.

Taking the chemical quality attributes (AV, PV, and TBA) as criteria of lipid auto-oxidation, Jute bags proved to be superior to the other three packaging materials in terms of minimizing the lipid auto-oxidation and hence prolonging the shelf-life,during storage at ambient temperature.

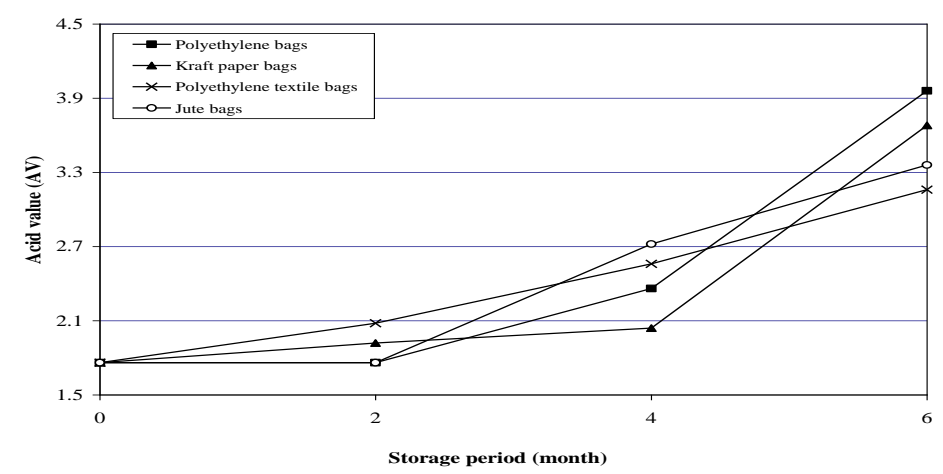

Fig. (2): Effect of packaging materials on acid value of dry masa flour 1 during storage.

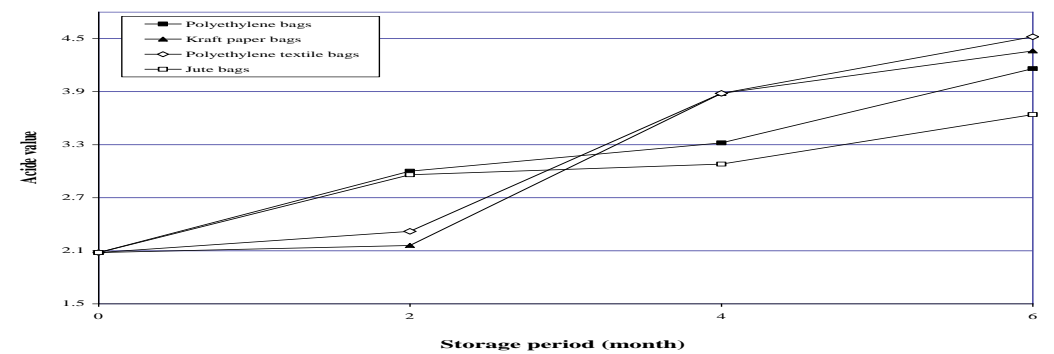

Fig. (3): Effect of packaging materials on acid value of dry masa flour 2 during storage. 
Hussein, A. M. S. and Nefisa A. Hegazy

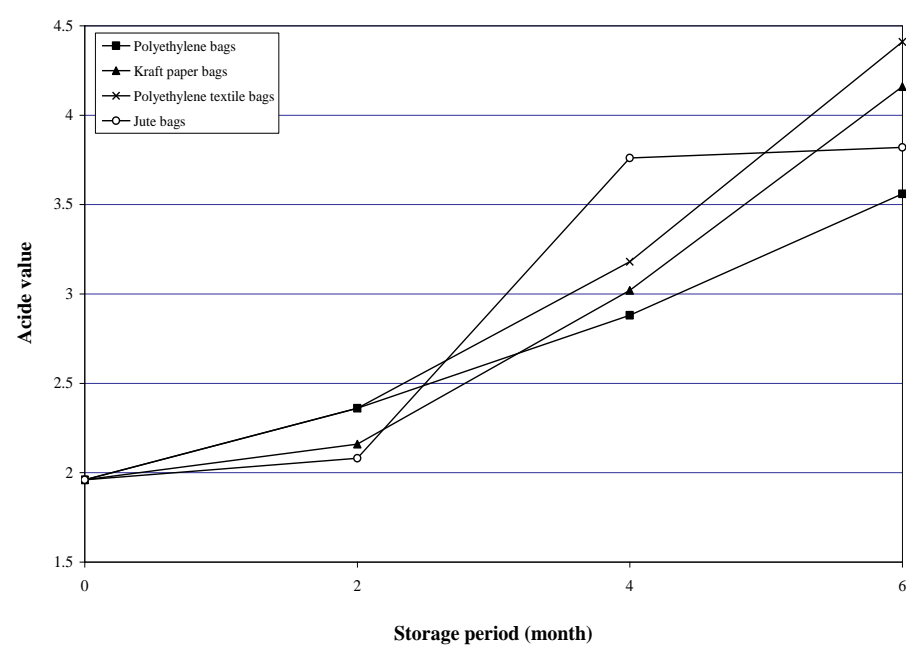

Fig. (4): Effect of packaging materials on acid value of dry masa flour 3 during storage.

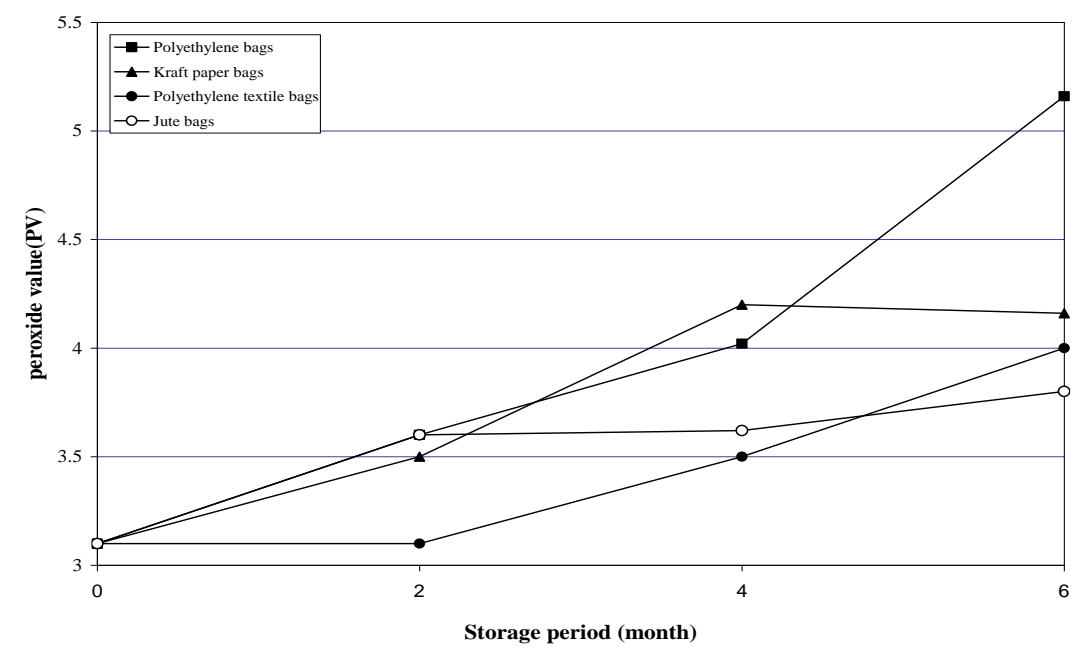

Fig. (5): Effect of packaging materials on peroxide value of dry masa flour1during storage. 
J. Agric. Sci. Mansoura Univ., 32 (9), September, 2007

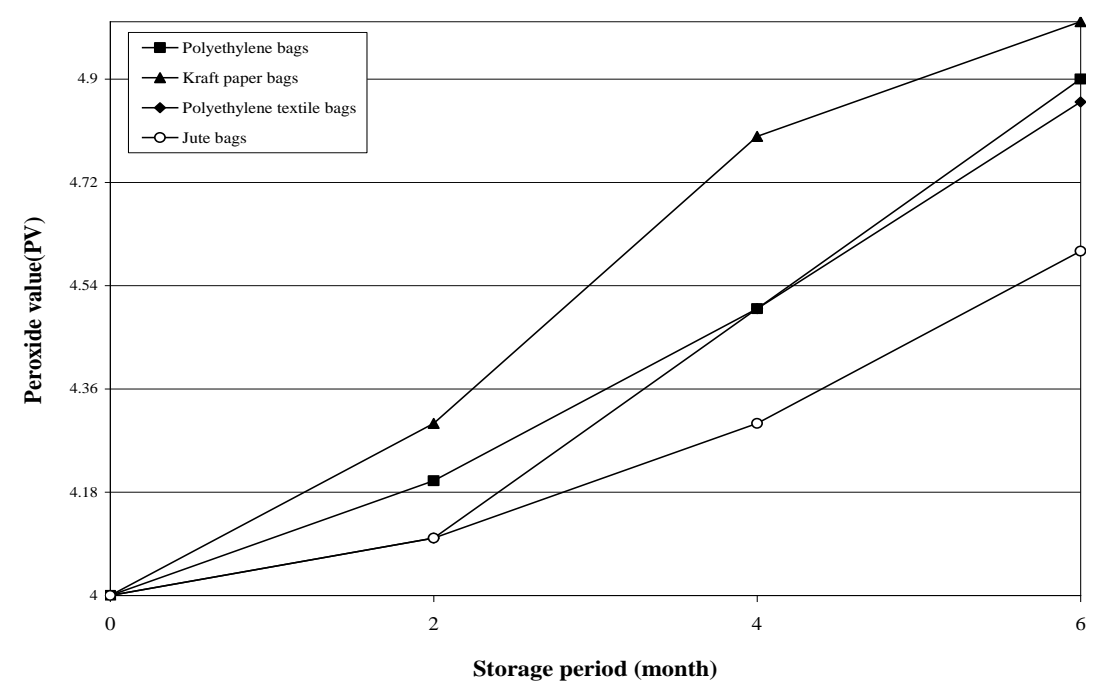

Fig. (6): Effect of packaging materials on peroxide value of dry masa flour2during storage.

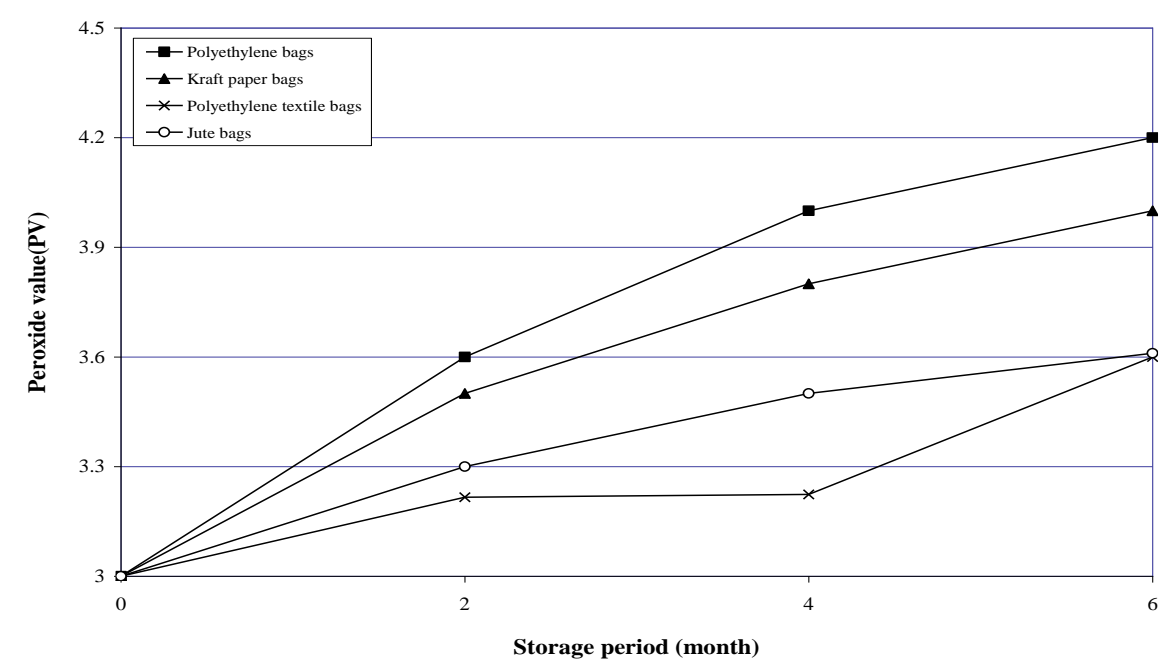

Fig. (7): Effect of packaging materials on peroxide value of dry masa flour 3 during storage. 
Hussein, A. M. S. and Nefisa A. Hegazy

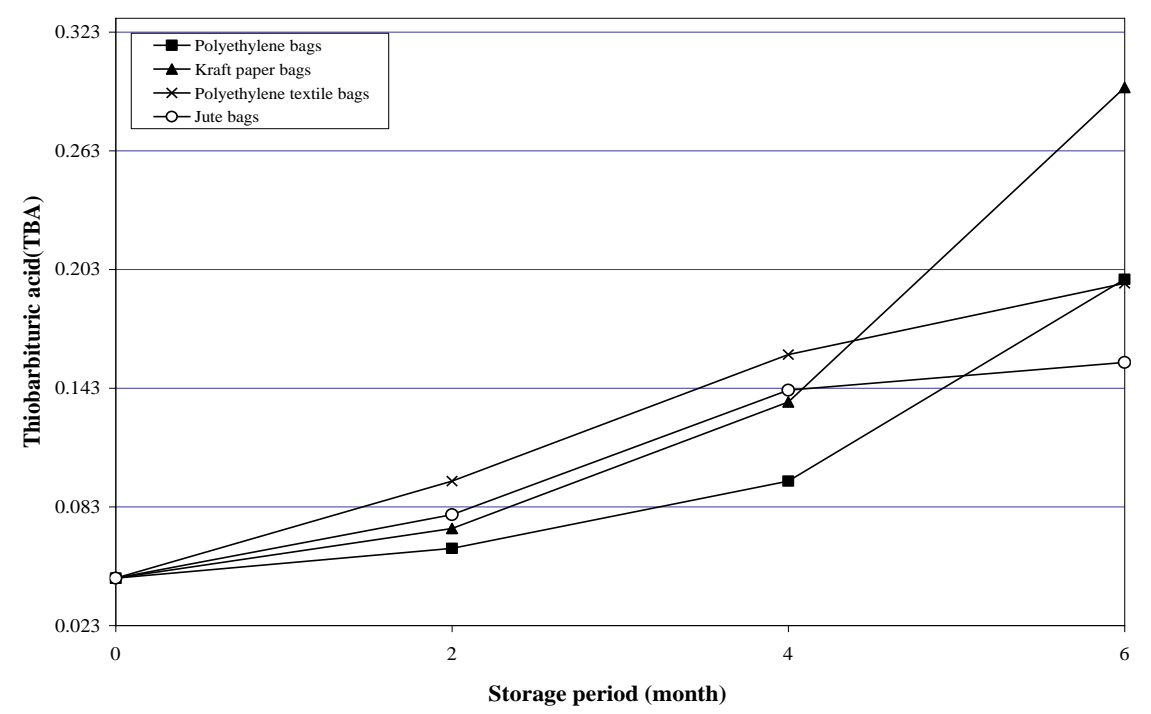

Fig. (8): Effect of packaging materials on thiobarbituric acid of dry masa flour1during storage.

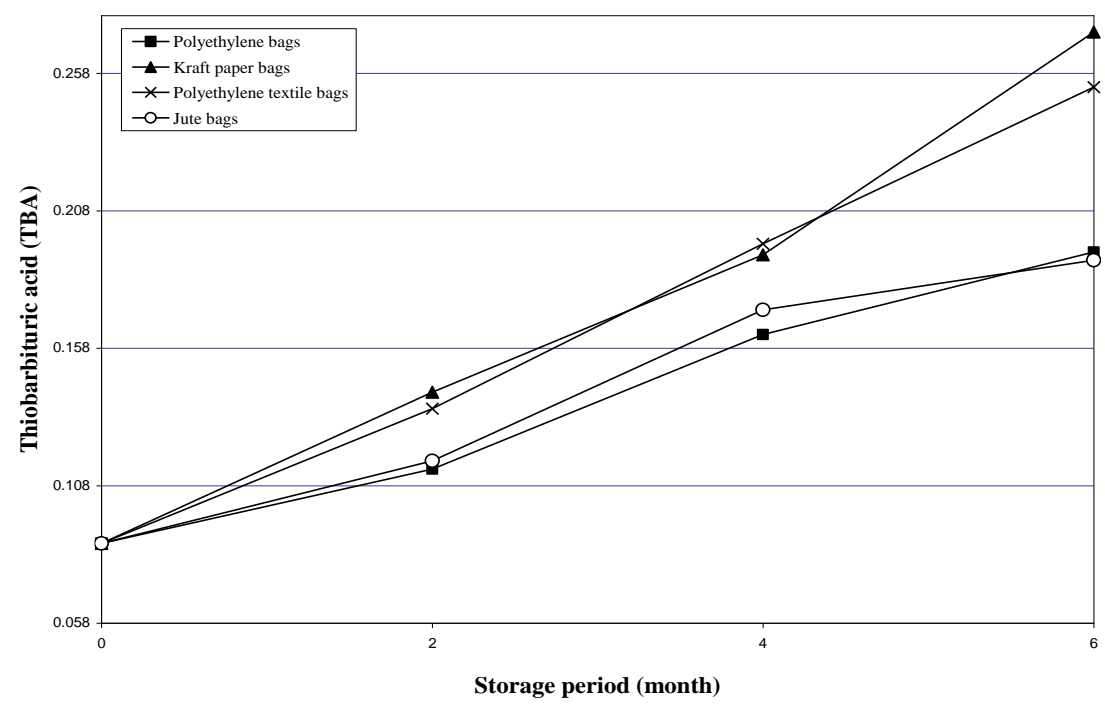

Fig. (9): Effect of packaging materials on thiobarbituric acid of dry masa flour 2 during storage. 


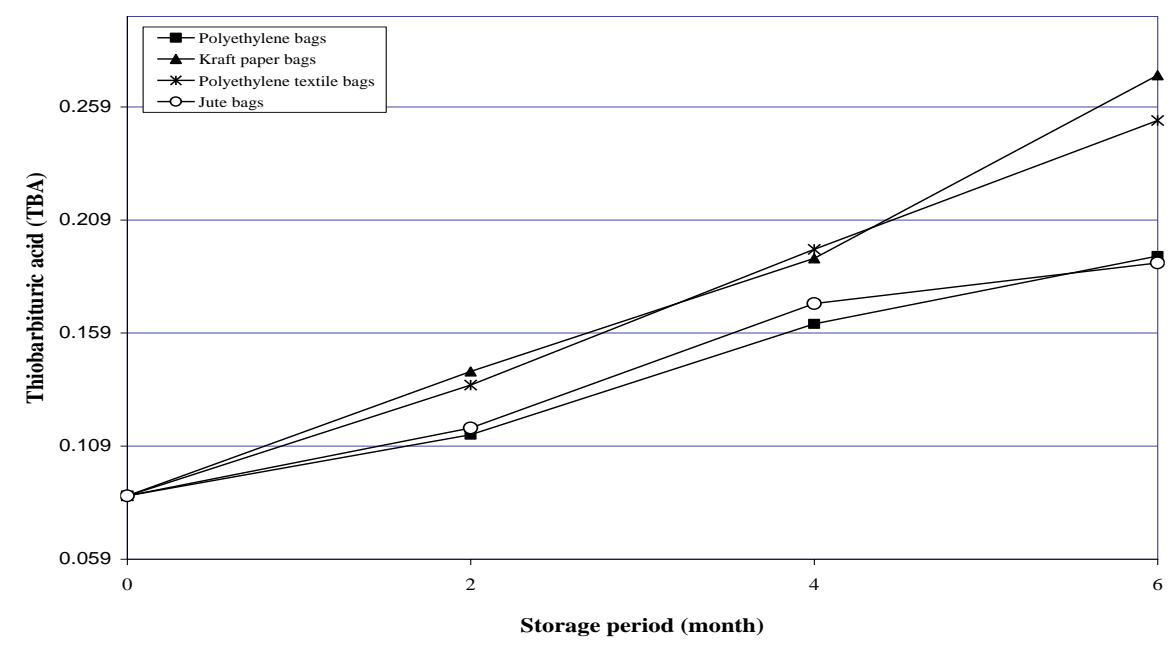

Fig. (10): Effect of packaging materials on thiobarbituric acid of dry masa flour 3 during storage.

\section{Effect of packaging material and storage on Amylograph profiles}

Maximum viscosity were higher in all the stored samples comared to the respective mean value found in the stored dry masa flours compared with the respective activities at zero time, suggesting a reduction in the amylase activities in the dry masa flours at zero time.Another characteristic of the dry masa flour is a lowering in the temperature of transition point among the stored masa samples (Table 5) compared with the respective initial value (Table 2).

Table (5): Effect of dry masa flour storage for 6 months on viscoamylograph reading.

\begin{tabular}{|l|c|c|c|c|c|}
\hline Packaging materials & Temperature (oc) & Viscosity (BU) \\
\cline { 2 - 6 } & $\begin{array}{c}\text { Transsion } \\
\text { point }\end{array}$ & Max.viscosity & Max. & Breakdown & Set back \\
\hline \multicolumn{7}{|c|}{ White corn Dry masa flour1 } \\
\hline Jute bags & 54 & 95 & 190 & 190 & 540 \\
\hline Kraft paper bags & 49.5 & 95 & 170 & 170 & 760 \\
\hline Polyethylene bags & 58.5 & 95 & 280 & 280 & 1160 \\
\hline Polyethylene textile bags & 58.5 & 95 & 380 & 380 & 1320 \\
\hline \multicolumn{7}{|c|}{ Yellow corn Dry masa flour2 } \\
\hline Jute bags & 52.5 & 95 & 190 & 190 & 1130 \\
\hline Kraft paper bags & 51 & 95 & 150 & 150 & 430 \\
\hline Polyethylene bags & 52.5 & 95 & 190 & 190 & 530 \\
\hline Polyethylene textile bags & 35 & 95 & 200 & 200 & 550 \\
\hline \multicolumn{7}{|c|}{ Sorghum Dry masa flour3 } \\
\hline Jute bags & 57 & 95 & 420 & 420 & 740 \\
\hline Kraft paper bags & 52 & 95 & 380 & 380 & 800 \\
\hline Polyethylene bags & 55.5 & 95 & 350 & 350 & 790 \\
\hline Polyethylene textile bags & 36 & 95 & 460 & 460 & 980 \\
\hline
\end{tabular}


The amylograph parameters of dry masa flours, i.e., the break down viscosity were lower than that of dry masa flours at zero time. The break down viscosity of dry masa flours packaged in kraft paper bags decreased more throughout storage than their counterparts packaged in jute bags, polyethylene and polyethylene textile.

The paste viscosity of dry masa flour packaged in kraft paper bags decreased more throughout storage than their counterparts packaged in polyethylene bags. These changes in viscosity may be due to amylolytic fungal activity that caused break down of starch.

\section{Sensory evaluation:}

Sensory quality of food indicates the basic nature of food or its degree of palatability and encompasses color, odor, texture and overall acceptability. Evaluation of the quality properties is an important part in the study of processing and storage effects in order to assure the achievement and maintenance of high quality degree. Fig.(11) presents the mean score value of the four studied organoleptic parameters of 72 dry maza samples .

Statistical analysis indicated the presence of significant interaction $(\mathrm{P}<0.05)$ between storage time and type of packaging; therefore differences between packaging systems at fixed storage times were studied. No significant difference $(P<0.05)$ was found between the different packaging materials during the first two months of storage could be detected by panelists. Masa flour packed in jute bags had the highest scores with regard to colour, flavour and aroma, compared with the respective scores obtained with those packed in other packaging materials.

Based on the results, it can be concluded that it is unsafe to pack dry maza flour in kraft bags or in polyethylene bags. Dry maza flour packed in kraft paper bags showed significant reduction $(P<0.05)$ in all sensory attributes after 4 months of storage with remarkable deterioration in the color scores (fig.11). More seriously, the panelists reported visible insect growth and high microbial counts. Associated with a moldy aroma in masa flours packed in kraft bags.

The sensory scores of the dry maza flours packed in polyethylene bags and stored for 4 months was also poor with slight rancid aroma detected by the panelists. . In this regard, Bothast et al. (1981) indicated that the sensory attributes (flavor and odor) of corn meal stored with the same moisture, deteriorated more rapidly at $34^{\circ} \mathrm{C}$ than at $25^{\circ} \mathrm{C}$. Furthermore, Paredes and Mora (1983) reported significant reductions in sensory scores in masa flour stored under accelerated conditions. 
J. Agric. Sci. Mansoura Univ., 32 (9), September, 2007
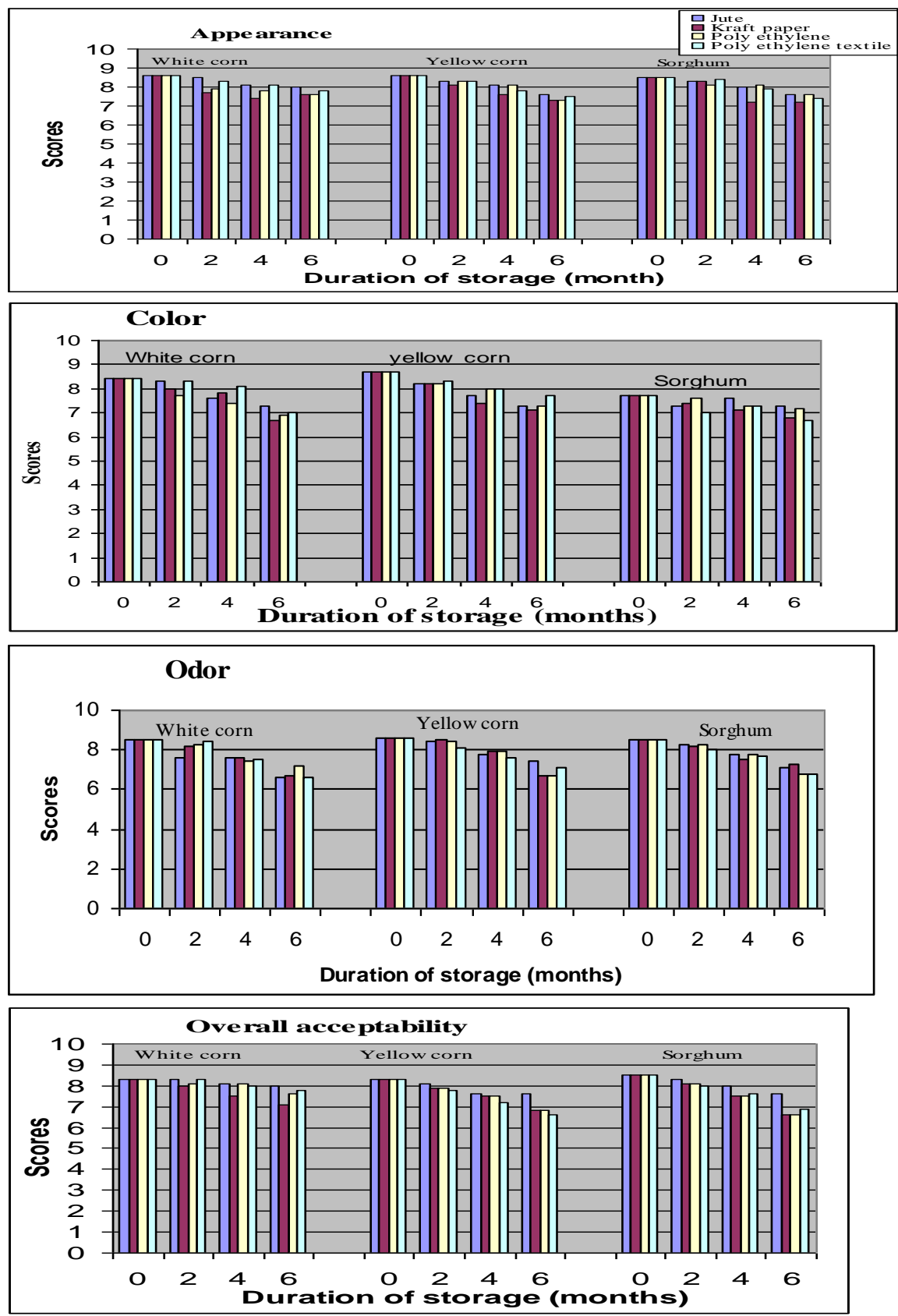

Fig (11): Sensory evaluation of dry masa prepared from white corn, yellow corn or sorghum packed in different packaging materials and stored for different periods of time 


\section{Conclusion}

The present study presented evidences that gelatinized flour could be produced from white corn, yellow corn or sorghum. The maximum shelf life of the prepared dry masa packed in jute or polyethylene bags is estimated to be four months when stored at $24-32{ }^{\circ} \mathrm{C}$ at $29 \% \mathrm{RH}$. The dry corn masa described in the present work could be used in the preparation of corn flakes; tortilla bread and tortilla chips thus introducing novel food commodities to the Egyptian market.

Acknowledgements: The authors wish to express their thanks to Prof. Laila Hussein, Department of Nutrition, at the National research Center, Giza ,Egypt for the revision of the manuscript.

\section{REFERENCES}

Aguilera, J.M. and Stanley, D.W. (1999). Microstructure principles of Food processing and Engineering, Second Edition. Chap . 5.p.185-241, in Food Structuring. Published in Aspen publishers, Inc. Gaithersburg, Maryland

Almeida- Dominguez, H.D.; Serna-Saldivar, S.O. and Rooney, L.W. (1991). Properties of new and commercial sorghum hybrids for use in alkaline cooked foods . Cereal Chem., 68 (1) : 25-31.

Anon.(2000).Statistic report. The economic Sector of Ministry of Agriculture, Egypt

A.O.A.C (1990) . Official Methods of Analyses of the Association of Official Analytical Chemists 15 th . ed., Arlington, Virginia 22201 U.S.A.

Barron, J.M. and Espinoza, A.(1993) . Fortification of maize tortilla with alkalitreated chickpea flour. International, J. Sci. and Technology,28(5)505511.

Bhattchary, M. and Hanna, M.A. (1987). Kinetics of starch gelatinization during extrusion cooking .J.Food Sci.,52(2):764-766.

Bothast, R., Anderson, R. A., Warner, K. and Kwolek, W.F.(1981).Effect of moisture and temperature on microbiological and sensory properties of wheat flour and corn meal during storage. Cereal Chem. , 58:309.

Bryant, C.M. and Hamaker, B.R. (1997) . Effect of lime on gelatinization of corn flour and starch. Cereal Chem.,74(2): 171-175.

Carrillo-Perez, E.,Serna-Saldivar,S.O. and Rouzaud-Sandez, O.(1989). Effect of storage condition and packaging materials on the physicochemical, microbial and sensory properties of corn dry masa flour. J. Food Processing Preservation 13, 335-353.

Chapman, H.D. and Pratt, P.F. (1978). Methods of analysis for soil, plants and water. P.50.Univ. of California, Div. Agric. Sci., Priced Publication 4034.

El-Shazly, A.S.I.(2001) . Studies on chemical and technological properties of some Egyptian cereal crops .Ph-D. Thesis, Depart . Agronomy- Crop Technology, Fac. Of Agric., Al-Azhar Univ., Egypt . 
Gomez, M.H.; Rooney, L.w.; Waniske, R.D. and Pflugfelder, R.L. (1987) . Dry corn masa flour for tortilla and snack food production. Cereal Foods World, 32 (5) : 372,373,375-377.

Gomez, M.H.; McDonough, C.M.; Rooney, L.W. and Waniske, R.D. (1989) . Changes in corn and sorghum during nixtamalization and tortilla baking. J. Food Sci., 54 (2):330-336 .

Gomez, M.H.; Waniska, Rooney, L.w. (1991) . Starch characterization of nixamalized corn flour. Cereal Chem., 68:578-582 .

Habib, A.T. and Brown, H.D.(1956) . Factors in fluencing the color of potato chips . Food Technology, March 12, $332-336$.

Hegazy, N.A; Faheid, S.M.M. and Ragab,G.H.(1996). Effect of different types packaging materials on quality of wheat flour. Bull. Fac. Agric Univ. Cairo, $47: 405-422$.

Hussein, A.M.S. (2002). Studies on tortilla chips produced from maize grains and sorghum .Ph.D. Thesis, Fac. Agric., Zagazig Univ., Egypt.

Kamel, M.M.(2001). Physico-chemical characteristics of Egyptian Jasmine rice as affected by under- pressure and Microwave parboiling methods. J.Agric. Sci. Mansoura Univ., 26 (12) : 7853-7868.

Khorshid , A.M.; Salem , E.M. and Hegazy, N.A. (1996) . Cooking parameters of corn and their effect on tortilla chips quality. Azhar $\mathrm{J}$. Agric . Res., 23: 1 - 11 (June).

Kies, C.(1985) . Nutritional bioavailability of calcium . American Chemical Society; Washington, DC.

functional properties and in vitro digestibility on lupin flour . Egypt, J. Food Sci., 15:161-168 .

Pardes,O. and Mora,R.E.(1983).Influence of storage on the quality of maize meal for tortilla making. Food Technology.,18:53-60.

Pearson, P. (1976).The chemical analysis of food $7^{\text {th }} \mathrm{Ed}$. Haney,Kony,Churcbill Livingstons Xii, 575 p.488-495.

Przybylski,R. and Eskin,N.A.M.(1995). Methods to measure volatile compounds and the flavor significant of volatile compounds. In Methods to Assess Quality and Stability of Oils and Fat. Containing Foods(K.Warner and N.A.M. Eskin,ed) pp 107-133,AOCS Press, Champaign, IL.

Rooney, L.W. and Serna-Saldivar, S.O. (1987). Food uses of corn and dry milled fractions ch. $13 \mathrm{In}$ Corn Chemistry and Technology. (S.A. Watson and P.E.Ramstad, eds.) Am. Assoc. Cer. Chem.St.Paul, Minn.

Salem, F.A.; Hegazy, N.A; Abd El-Moneim, S.M.; Shalaby, A.R. and Hussein A.M. (1999a). Evaluation Egyptian corn varieties for tortilla bread production. $6^{\text {th }}$ Arabic Conference on Food Science \& Technology, March $16-18^{\text {th }}$, Cairo - Egypt .

Sanchez-Marroquin, A.; Feria - Morales, A.; Maya, S. and Ramos - Moreno, V. (1987). Processing, nutritional quality and sensory evaluation of amaranth enriched corn tortilla . J. Food Sci., 52 (6) : $1611-1614$.

Serna - Saldivar, S.O.; Rooney, L.W. and Green, L.W. (1991) . Effect of lime treatment on the availability of calcium in diets of tortillas and beans: rat growth and balance studies. Cereal Chem., 68 (60) : 565 - 570 . 
Snedecor,G.W. and Cochran,W. G. (1980).Statistical Methods , $7^{\text {th }}$ Ed. Oxford and IBIT Publ.C3o.

Tonella, M.L., Sanchez, M. and Salazar, M.G. (1983) . Physical, chemical, nutritional and sensory properties of corn based fortified food products. J. Food Sci., 48: 1637 - 1640.

Twillman,T.J. and White,P.J.(1988). Inflence of monoglycerides on textural, shelf- life and dough rheology of corn tortillas. Cereal Chem., 65:253257.

Vidal-Quintanar, R.L.,Love, M. R. and Johnson, L.A.(1993). Role of lipid in flavor and dough properties of corn flour. Cereal Food World .,28:612613.

Vidal-Quintanar, R.L.,Love, M. R. and Johnson, L.A (2001). Role of oil on physical properties of corn masa flours and sensory characteristics of corn tortillas. J. Food Processing and Preservation .,25: 1-14.

Vidal-Quintanar, R.L, Mark, H. L., Pamela, A.J. ,Love, M. R and Johnson, L.A.(2003) Lipid-autoxidation-limited shelf-life of nixtamalized instant corn masa. J. Food Lipids. 10: 153-163.

Zahran, G.A.H. (2000). Effect of extrusion processing on the properties of snack food manufactured from some cereals and legumes blends. Ph.D. Thesis, Depart. Food Sci. \&Tech., Fac. of Agric., Cairo Univ., Egypt.

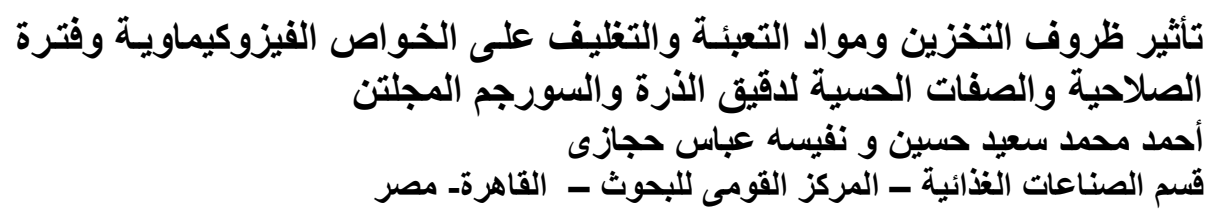

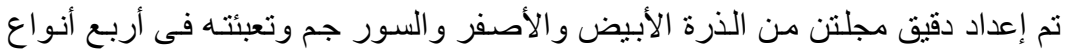

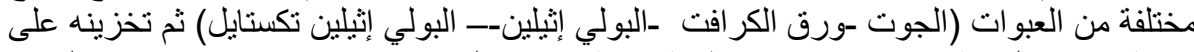

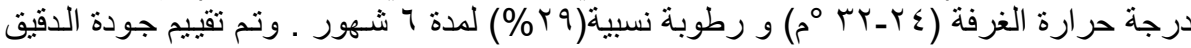

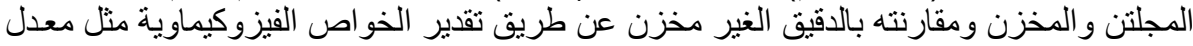

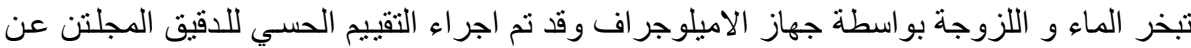
طريق اربع صفات مختلفة.

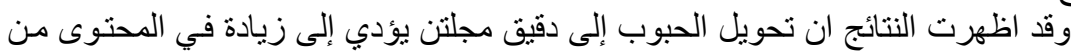

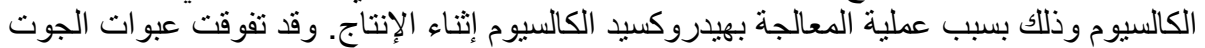

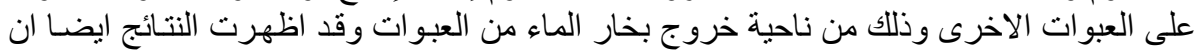

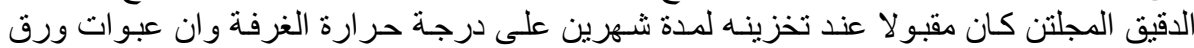

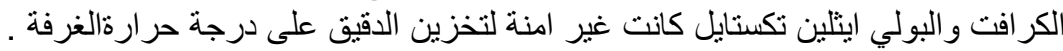


J. Agric. Sci. Mansoura Univ., 32 (9): 7417 - 7435, 2007

Table (2): Amylographic characteristics of types flours.

\begin{tabular}{|c|c|c|c|c|c|c|c|c|c|c|c|c|c|c|c|}
\hline \multirow{3}{*}{ Varieties } & \multicolumn{6}{|c|}{ Temperature $\left({ }^{\circ} \mathrm{C}\right)$} & \multicolumn{9}{|c|}{ Viscosity (BU) } \\
\hline & \multicolumn{3}{|c|}{ Transsion point in } & \multicolumn{3}{|c|}{ Max.viscosity in } & \multicolumn{3}{|c|}{ Maximum } & \multicolumn{3}{|c|}{$\begin{array}{c}\text { Breakdown } \\
\text { (after } 15 \mathrm{~min} \text { at } 95^{\circ} \mathrm{C} \text { ) }\end{array}$} & \multicolumn{3}{|c|}{$\begin{array}{l}\text { Set back } \\
\left(\text { at } 50^{\circ} \mathrm{C} \text { ) }\right.\end{array}$} \\
\hline & Flour & \begin{tabular}{|l} 
Flour+1 \\
\%lilime
\end{tabular} & $\begin{array}{c}\text { Treated } \\
\text { flour }\end{array}$ & Flour & \begin{tabular}{|l|} 
Flour+1 \\
\%lilime
\end{tabular} & $\begin{array}{c}\text { Treated } \\
\text { flour }\end{array}$ & $\mathbf{F}$ & $\begin{array}{c}\begin{array}{c}\text { Flour+1 } \\
\% \text { lime }\end{array} \\
\end{array}$ & $\begin{array}{c}\text { Treated } \\
\text { flour }\end{array}$ & Flour & $\begin{array}{c}\begin{array}{c}\text { Flour+1 } \\
\% \text { lime }\end{array} \\
\text { \% }\end{array}$ & $\begin{array}{c}\text { Treated } \\
\text { flour }\end{array}$ & Flour & $\begin{array}{c}\text { Flour+1 } \\
\text { \%lime }\end{array}$ & $\begin{array}{l}\text { Treated } \\
\text { flour }\end{array}$ \\
\hline White corn & 90 & 69 & 72 & 98 & 84 & 98 & 1130 & 1960 & 250 & 960 & 1400 & 500 & 3640 & 2900 & 1120 \\
\hline Yellow corn & 82 & 58.5 & 70.5 & 98 & 85.5 & 94.5 & 1420 & 1580 & 170 & 1430 & 1200 & 330 & 5000 & 3400 & 700 \\
\hline Sorghum & 80.5 & 70.5 & 63 & 97.5 & 85 & 95 & 440 & 2080 & 200 & 520 & 2600 & 420 & 1480 & 4520 & 880 \\
\hline
\end{tabular}

$\frac{\text { Where: }}{\text { BU: Brabender unit }}$ 